\title{
IMPLEMENTASI PENDEKATAN SOSIOLINGUISTIK DALAM
}

\section{PEMBELAJARAN BAHASA ARAB}

\author{
Nurhapsari Pradnya Paramitha \\ Dosen Tetap Program Studi Pendidikan Bahasa Arab \\ STAI Masjid Syuhada Yogyakarta \\ Email : jannah_484@yahoo.com
}

Abstrak

Sosiolinguistik merupakan cabang linguistik yang secara etimologi kata tersebut berasal dari bahasa Inggris, yaitu terdiri atas kata socio dan linguistics. Linguistik yaitu ilmu yang mempelajari atau membicarakan bahasa, khususnya unsur-unsur bahasa (fonem, morfem, kata, kalimat) dan hubungan antara unsur-unsur itu termasuk hakikat dan pembentukan unsur -unsur itu. Unsur sosio adalah seakar dengan sosial, yaitu yang berhubungan dengan masyarakat, kelompok-kelompok masyarakat, dan fungsi kemasyarakatan. Jadi, sosiolinguistik adalah studi atau pembahasan dari bahasa sehubungan dengan penutur bahasa itu sebagai anggota masyarakat. Dapat juga dikatakan bahwa sosiolinguistik mempelajari dan membahas aspek-aspek kemasyarakatan bahasa, khususnya perbedaan-perbedaan (variasi) yang terdapat dalam bahasa yang berkaitan dengan faktor-faktor kemasyarakatan (sosial).

Kata kunci : sosiolinguistik, variasi bahasa

\section{Abstract}

Sociolinguistics is a branch of linguistics that etymologically the word comes from the English language, which consists of words socio and linguistics. Linguistics is the study of language, especially the elements of language (phonemes, morphemes, words, sentences) and the relationships between these elements including the nature and formation of the elements. The socio element is social, which is related to society, community groups, and community functions. Thus, sociolinguistics is the study or discussion of the language with respect to the speakers of that language as members of society. It can also be said that sociolinguistics studies and discusses aspects of the societal 
Nurhapsari Pradnya Paramitha : Implementasi Pendekatan Sosiolinguistik

language, especially the differences (variations) contained in language related to social faktors (social).

Keywords: sociolinguistics, language variation

\section{A. Pendahuluan}

Secara naluriah manusia terdorong untuk menyatakan eksistensinya, mengekspresikan perasaannya, menyalurkan aspirasinya, memberikan pendapatnya maupun mempengaruhi orang lain demi kepentingan sendiri, kepentingan kelompok, maupun kepentingan bersama. Berkenaan dengan hal tersebut, tentu bahasa memiliki peranan yang sangat penting ${ }_{129}$. Bahasa merupakan kumpulan simbol yang digunakan sebagai alat komunikasi. Bahasa dikatakan simbol karena ia menunjukkan identitas kelompok masyarakat secara sosiokultural. Bahasa bisa digunakan sebagai identitas sekelompok orang, satu masyarakat, satu bangsa, bahkan juga digunakan sebagai identitas global dalam lingkup antar negara. Bahasa disebut sebagai mediator karena posisinya dalam komunikasi antar manusia sebagai penghubung dan pemindah maksud sebuah interpretasi. Baik sebagai simbol dan mediator, bahasa dipandang memiliki wewenang yang sangat kuat dalam diri manusia, sekaligus sebagai ciri pembeda dengan makhluk bernyawa lainnya. Bahasa yang secara inheren menyertai manusia juga berkembang sebagaimana manusia itu sendiri.

Bahasa memiliki cakupan yang sangat luas dan menakjubkan. Berbahasa merupakan kegiatan manusia

129Mark Aronoff And Janie Rees-Miller, The Handbook of Linguistics, (UK: Blackwell Publishing, 2002) Hal 425, bisa juga diakses secara online dihttp://www.blackwellreference.com/subscriber/book?id=g9781405102520_ $\underline{9781405102520}$

164 Jurnal Komunikasi dan Pendidikan Islam, Volume 6, Nomor 2, Desember 2017 
setiap saat dalam berhubungan dengan orang lain. Bila dilihat dari fungsinya, bahasa merupakan alat mengkomunikasikan perasaan, pikiran, dan gagasan kepada orang lain. Karenanya para pemerhati ilmu sosial memasukan bahasa ke dalam gejala sosial. Sebagai gejala sosial tentu saja bahasa dipengaruhi oleh faktor-faktor eksternal, seperti faktor masyarakat, tingkat pendidikan, tingkat ekonomi, jenis kelamin, umur, lingkungan, dsb. Faktor lainnya adalah faktor situasional; siapa yang berbicara, dengan bahasa apa pembicaraan itu dilaksanakan, kepada siapa, kapan, di mana, dan tema dalam pembicaraan tersebut. Karena faktor-faktor inilah terjadi variasi bahasa dalam masyarakat bahasa, walaupun mereka menggunakan bahasa yang sama, misalnya sama-sama menggunakan bahasa Indonesia, tetapi dapat dijumpai istilah-istilah atau cara penyampaian yang berbeda untuk menyampaikan hal yang sama130.

Secara umum, Sosiolinguistik mempelajari tentang masalah-masalah sosial dan hubungannya dengan masyarakat.131 Sosiolinguistik telah menjadi ilmu yang mandiri yang memiliki fokus kajian dalam mempelajari bahasa dan hubungannya masyarakat. Setiap sisi-sisi bangunan bahasanya sangat teratur, metode pemakaiannya berkaitan dengan fungsi-fungsi sosial dan kebudayaan. Oleh karena itu, kita harus memberikan perhatian yang dalam kepada pemakaian istilah atau satu nama sebagai tema terhadap pembahasan ini. Karena pembelajaran bahasa dan hubungannya dengan masyarakat dan kebudayaan

130Abdurrahman, Sosiolinguistik: Teori, Peran, dan Fungsinya terhadap Kajian Sastra, (Malang: Jurnal Lingua, UIN Malang, 2005), hlm. 89-90 131Muhammad Daud, al Arabiyah wa Ilm al Lughoh al Ijtima'i, (Kairo: Dar Gharib, 2001), hlm. 91 
cakupannya sangat luas sekali. Dan cukuplah kita mempelajari ilmu-ilmu atau cabang-cabang lain yang sama dengan tema ini berdasarkan pada suatu pembelajaran dengan beberapa nama yang berbeda. Akan tetapi, diantara ilmu-ilmu ini terdapat suatu keruwetan atau intervensi sebagaimana tampak dengan terang pada nama-nama yang muncul sekarang terhadap ilmu-ilmu ini yang menginginkan tema ini dari satu sisi atau sisi yang lain sebagai peran untuk pemahaman ilmu yang sebenarnya132.

Para pakar juga menggunakan nama-nama yang lain yang sesuai dengan Sosiolinguistik yaitu sosiologi bahasa, antropologi bahasa, atau etnologi bahasa. Istilah Sosiolinguistik dalam bahasa Inggris terdapat dua nama yaitu: Sociological Linguistics dan Social Linguistics. Dari tiga nama di atas, kita mengambil istilah Sosiolinguistik karena ia lebih terkenal dalam segi pemakaian dan lebih banyak kepastiannya, tetapi sebenarnya tiga nama tersebut adalah satu133. Ada juga pendapat lain bahwa istilah The Sociology of Language menurut sebagian linguis adalah sama dengan istilah Sociolinguistics dalam hal pemakaiannya. Artinya bahwa keduanya bisa saling menggantikan antara satu dengan yang lain terhadap sesuatu atau satu cabang dari pembelajaran bahasa sosial atau sosial bahasa, dan yang lainnya berbeda. Bagi mereka berbeda dalam hal tingkatan perhatian. Perbedaan tersebut dilihat dari segi penekanannya, yaitu titik tekan dari segi bahasa dan titik tekan dari segi hlm. 41

132Kamal Basyar, Ilm al Lughoh al Ijtima'i, (Kairo: Dar Ghorib, 1997), 133Ibid, hlm. 41

166 Jurnal Komunikasi dan Pendidikan Islam, Volume 6, Nomor 2, Desember 2017 
sosial134. Kita di sini akan membedakan antara beberapa istilah yang di dalamnya terdapat kerancuan atau ketidakjelasan dalam hal cakupannya, sehingga kita bisa membedakan antara satu dengan yang lain.

Sosiologi mencakup tentang hal ekonomi dan sosial, sebagaimana mencakup tentang agam-agama, psikologi, kebudayaan dan bahasa, ia juga memusatkan pada pendidikan, politik dan geografi. Di sana ada sosiologi hukum, sosiologi ekonomi, sosiologi agama, sosiologi psikolog, sosiologi kebudayaan, sosiologi bahasa, sosiologi pendidikan, sosiologi politik, dan sosiologi geografi. Semua ilmu di atas adalah tingkatan yang saling berkaitan. Ia berangkat dari materi yang disentuh (seperti realita geografi) yang kemudian sampai kepada tingkatan jiwa dan akal dan terus-menerus dengan aturan-aturan sosial, peran-peran, simbol dan nilai135.

Sosiologi bagi salah satu tingkatan ini memiliki cakupan khusus, yaitu ilmu sosial. Adapun realita geografi dipelajari oleh morfologi sosial, realita jiwa dipelajari oleh psikologi sosial, realita kebudayaan dipelajari oleh ilmu kebudayaan sosial, dan realita bahasa dipelajari oleh Sosiolinguistik. Istilah Sosiologi adalah istilah sebagai ganti dari sosiologi bahasa. Karena istilah yang pertama lebih banyak pertautan dengan perbuatan kita Adapun fungsi Sosiolinguistik adalah

134Muhammad Farkhan setidaknya membedakan keduanya dari fokus kajiannya. Sosiolinguistik memberikan perhatian terhadap bahasa dan pengaruh masyarakat terhadapnya. Sementara sociology of language fokus terhadap bahasa dan pengaruhnya terhadap masyarakat. Dia mengatakan,"Sociolinguistics differs from sociology of language in that the focus of sociolinguistics is the effect of the society on the language, while the latter's focus is on the language's effect on the society". Muhammad Farkhan, Sociolinguistics: A Basis for Language Use Analysis, (ELL Journal, Vol. 1, No. 1, March 2008) hlm. 37-44

135Kamal Basyar, op. cit, 43, lihat juga Muhammad Farkhan, Applied Linguistics, (ELL Journal, Vol. 1, No. 2, September 2008) hlm. 111-116 
meneliti metode-metode yang saling mempengaruhi atau berinteraksi antara fenomena-fenomena bahasa dan sosial. Sesungguhnya Sosiolinguistik melihat perubahan-perubahan yang menyebabkan bangunan bahasa sebagai respon terhadap fungsi-fungsi sosial yang berbeda, dimana ia sebenarnya menerangkan fungsi-fungsi dan batasanbatasannya136. Sosiolinguistik juga memperhatikan tentang pembelajaran bahasa dan jenis, kekususan bahasa untuk laki-laki dan untuk perempuan ${ }_{137}$, sama juga dari sisi tinggi rendahnya suara atau jenis kata yang melekat di antara keduanya. Ia juga memperhatikan sisi pembelajaran tentang hal-hal yang dilarang atau tidak pantas dalam percakapan.

\section{B. Pemahaman Tentang Sosiolinguistik}

Kata Sosiolinguistik merupakan gabungan dari kata Sosiologi dan Linguistik. Sosiologi adalah kajian yang objektif dan ilmiah mengenai manusia dalam masyarakat dan mengenai lembaga-lembaga serta proses sosial yang ada di dalam masyarakat. Sedangkan Linguistik adalah ilmu bahasa atau bidang yang mengambil bahasa sebagai objek kajiannya. Dengan demikian, Sosiolinguistik merupakan bidang ilmu antar disiplin atau inter dan multidisipliner yang mempelajari bahasa di dalam masyarakat.Appel mengatakan, Sosiolinguistik memandang bahasa sebagai sistem sosial dan sistem komunikasi serta merupakan bagian dari masyarakat dan kebudayaan tertentu. Dengan demikian, dalam Sosiolinguistik, bahasa tidak dilihat secara internal, tetapi

136Ibid, hlm. 47

137Mark Aronoff And Janie Rees-Miller, op. cit, hlm. 435

168 Jurnal Komunikasi dan Pendidikan Islam, Volume 6, Nomor 2, Desember 2017 
dilihat sebagai sarana interaksi atau komunikasi di dalam masyarakat.

Di dalam masyaarakat seseorang tidak lagi dipandang sebagai individu yang terpisah, tetapi sebagai anggota kelompok sosial. Oleh karena itu, bahasa dan pemakaiannya tidak diamati secara individual, tetapi dihubungkan dengan kegiatannya dalam masyarakat atau dipandang secara sosial. Dipandang secara sosial, bahasa dan pemakaiannya dipengaruhi oleh faktor linguistik dan nonlinguistik. Faktor nonlinguistik terdiri dari faktor sosial dan faktor situasional. Yang termasuk ke dalam faktor sosial diantaranya, status sosial, tingkat pendidikan, umur, jenis kelamin, dan lain-lain. Sedangkan faktor situasional terdiri dari siapa yang berbicara, dengan bahasa apa, kepada siapa, dimana, masalah apa, dan lain-lain 138.

Sosiolinguistik mengkaji bahasa dengan memperhitungkan hubungan antara bahasa dengan masyarakat, khususnya masyarakat penutur bahasa itu. Jadi jelas, Sosiolinguistik mempertimbangkan keterkaitan dua hal, yakni Linguistik dari segi kebahasaan dan Sosiologi untuk segi kemasyarakatan. Haugen mengemukakan, dalam makalahnya "Some Issues in Siciolinguistics" dalam sebuah buku yang berjudul "Issues in Siciolinguistics", bahwa istilah Sosiolinguistik pertama kali diperkenalkan oleh Haver C. Currie yaitu seorang guru besar (Profersor) di Universitas Houston, Texas pada tahun 1952. Istilah ini kemudian dipublikasikan di Amerika oleh William Bright dan dipresentasikan dalam sebuah kongres Linguistik Internasional VIII di Cambridge pada tahun 1962, kemudian dikembangkan lagi dalam sebuah Konferensi Internasional

138 Aslinda dan Leni Syafyahya, Op. cit, hlm. 6 
yang lebih formal di Los Angeles, California pada tahun 1962, dan menjadi popular hingga sekarang 139 .

Istilah Sosiolinguistik yang menekankan tentang pengkajian bahasa dalam hubungannya dengan masyarakat, ada beberapa pakar yang mengemukakannya, Hymes mengemukakan bahwa, "the term Sociolinguistics to the correlations between language and societies particular linguistics and social phenomena". Artinya adalah istilah Sosiolinguistik untuk menghubungkan antara bahasa dan masyarakat serta bahasa dan fenomena dalam masyarakat. Bahkan Chaklader sendiri mensinyalir bahwa, "Sociolinguistics concertretes its study upon societally patterned variation in language usage". Artinya, Sosiolinguistik menekankan pada pengkajian atas variasi pola-pola masyarakat dalam penggunaan bahasa. Hal senada juga diugkapkan oleh Hudson bahwa, "Sociolinguistics as the study of language in relation to society, inplying (intentionally) that Sociolinguistics is part of the study of language". Artinya, Sosiolinguistik sebagai pengkajian bahasa dalam hubungannya dengan masyarakat mengimplikasikan bahwa Sosiolinguistik merupakan bagian dari ilmu bahasa.

Pendefinisian lain yang senada adalah pendapat Pride, "Sociolinguistics to study every aspect of use language that relates to its social and cultural functions". Maksudnya adalah Sosiolinguistik itu untuk meneliti setiap aspek dari penggunaan bahasa yang berhubungan dengan fungsi sosial dan fungsi budaya (Chaklader, 1990:2) 140. Suwito

139 Abdurrahman,Makalah Sosiolinguistik: Campur Kode, Alih Kode dan Karakteristik Bahasa Sastra dalam sebuah Novel Bekisar Merah, (Malang: UINMalang, 2007), hlm. 4 140 Abdurrahman, Op. cit, hlm. 5

170 Jurnal Komunikasi dan Pendidikan Islam, Volume 6, Nomor 2, Desember 2017 
mengemukakan bahwa Sosiolinguistik mempelajari bahasa dalam konteks sosio-kultural serta situasi pemakainya141. Dengan demikian dapat disimpulkan bahwa bahasa tidak saja dari sudut penuturnya, tetapi juga dari sudut pendengarnya, karena pemakaian bahasa pada hakekatnya adalah proses interaksi verbal antara penutur dan pendengarnya. Dalam proses interaksi, baik penutur maupun pendengar selalu mempertimbangkan kepada siapa ia berbicara, di mana, kapan, mengehai masalah apa, dan dalam situasi bagaimana, dan sebagainya seperti yang telah dijelaskan oleh Fishman.

\section{Manfaat Sosiolinguistik}

Sosiolinguistik merupakan studi tentang sifat-sifat bahasa, variasi bahasa, fungsi bahasa, dan pemakaian bahasa dalam jalinan interaksi serta fungsi bahasa dalam masyarakat. Sumbangan yang dapat diberikan oleh Sosiolinguistik antara lain:

1. Sosiolinguistik dapat memberikan gambaran tentang keadaan sosial suatu masyarakat berkaitan dengan bahasanya

2. Sosiolinguistik dapat digunakan untuk mendeskripsikan adanya variasi-variasi yang ada dalam masyarakat tertentu

3. Sosiolinguistik dapat membantu untuk menentukan atau memilih variasi bahasa mana yang akan kita gunakan yang sesuai dengan situasi dan fungsinya 142 .

Taufiq Muhammad Syahin menambahkan bahwa, manfaat Sosiolinguistik antara lain sebagai berikut:

141Suwito, Sosiolinguistik, (Surakarta: Sebelas Maret University Press, 1996), hlm. 2

142Abdurrahman. Op. Cit. hlm. 7, lihat juga Mark Aronoff And Janie Rees-Miller, op. cit, hlm 434 
1. Sosiolinguistik dapat digunakan untuk mendefinisikan perubahan bahasa secara sempurna sesuai dengan faktorfaktor kebahasaan.

2. Sosiolinguistik dapat membantu untuk menunjukkan bahwa aspek Linguistik merupakan fenomena penting dalam perilaku masyarakat, dan sebagai sebab kemajuan individu dalam masyarakatnya143.

\section{Beberapa Cakupan dalam Sosiolinguistik}

Sosilingustik dalam kajiannya yang mendalam kemudian memberikan beberapa perhatian terhadap fenomenafenomena bahasa, diantaranya:

1. Bilingualisme

Suatu masyarakat atau daerah yang memiliki atau memakai dua bahasa, maka masyarakat atau daerah itu disebut daerah atau masyarakat yang berdwibahasa atau bilingual. Orang yang dapat menggunakan dua bahasa disebut dwibahasawan atau orang yang bilingual144. Dalam percakapan (komunitas bilingual), level bahasa tersebut ditandai dengan adanya pergantian dari varietas satu ke varietas lainnya. Alasan paling tepat untuk menjelaskan adanya variasi bahasa ini dan patokan pemilihan penggunaan varietas bahasa adalah berdasarkan tingkat kepedulian dari pembicara dan penulis terhadap ekspresinya (ucapan dan penulisannya), serta level lawan bicara. Semakin formal acara atau situasi, semakin besar tingkat kehati-hatian yang diberikan.

143Taufiq Muhammad Syahin, Ilm Al-Lughoh Al-Amm, (Mesir : Maktabah Wahbah, 1980), hlm. 135

144Nababan P.W.J., Sosiolinguistik: Suatu Pengantar,(Jakarta: Gramedia Pustaka Utama, 1993), hlm. 27

172 Jurnal Komunikasi dan Pendidikan Islam, Volume 6, Nomor 2, Desember 2017 
Jadi Bilingualisme adalah kebiasaan menggunakan dua bahasa dalam interaksi dengan orang lain. Orang yang berdwibahasa mencakup pengertian kebiasaan memakai dua bahasa, atau kemampuan memakai dua bahasa. Menurut Nababan membedakan kedwibahasaan dan kedwibahasawanandengan menggunakan istilah bilingualisme atau bilingualitas.

Hubungan antara bilingualisme dan bilingualitas adalah tidak semua yang mempunyai bilingualitas mempraktekkan bilingualisme dalam kehidupan seharihari, sebab ini tergantung pada situasi kebahasaan lingkungannya. Namun dapat juga kita mengerti bahwa tidak dapat seseorang mengejakan bilingualisme tanpa juga dia mempunyai bilingualitas, atau seseorang harus mempunyai dahulu bilingualitas sebelum dia dapat mengerjakan bilingualisme 145 . Namun pengertian tentang kedwibahasaan selalu berkembang yang mana ia mempunyai kecenderungan yang meluas karena istilah kedwibahasaan bersifat nisbi atau relatif ${ }_{146}$. Pada mulanya, kedwibahasaan selalu diartikan sebagai native control of two languages (menguasai seperti menguasai bahasa ibunya) 147.

Harimurti Kridalaksana dalam mempermudah pemahaman membagi kedwibahasaan (bilingualisme), dia membaginya kedalam tiga kategori:

a. Bilingualisme Koordinat (Coordinate Bilingualism), yaitu penggunaan bahasa dengan dua atau lebih sistem bahasa yang terpisah. Seseorang bilingual koordinat, 
tidak menggunakan satu bahasa, tidak menampakkan unsur-unsur bahasa lain, pada waktu beralih ke bahasa lain tidak terjadi percampuran sistem.

b. Bilingualisme Majemuk (Compound Bilingualism), di sini penutur bahasa menggunakan dua sistem atau lebih yang terpadu. Seorang bilingual mejemuk sering mengacaukan unsur-unsur dari kedua bahasa yang dikuasainya.

c. Bilingualisme Sub-Ordinat (Sub-Ordinat Bilingualisme), terjadi pada seseorang atau masyarakat yang menggunakan dua sistem bahasa atau lebih secara terpisah. Yang masih cenderung mencampuradukkan konsep-konsep bahasa pertama ke dalam bahasa asing yang dipelajarinya 148.

Dari penjelasan di atas, dapat dicermati bahwa kedwibahasaan memperlihatkan beberapa ciri antara lain:

a. Kedwibahasaan terjadi akibat adanya kontak bahasa, yang merupakan gejala bahasa (langue) yang selayaknya nampak dalam kedwibahasaan yang merupakan gejala tutur (parole) dan langue merupakan sumber parole.

b. Kedwibahasaan erat kaitannya dengan dwibahasawan, karena keberadaan dwibahasawan menentukan ada tidaknya kedwibasaan.

c. Kedwibahasaan merupakan pemakaian dua bahasa secara bergantian oleh seorang penutur sehingga dalam kedwibahasaan paling tidak harus ada dua bahasa atau lebih.

148Abdurrahman. Op. Cit,hlm. 11, lihat juga Abd. Syukur Ibrahim, Sosiolinguistik: Sajian, Tujuan, Pendekatan dan Problem, (Surabaya: Usaha Nasional, 1995), hlm 181-182 
Nurhapsari Pradnya Paramitha : Implementasi Pendekatan Sosiolinguistik

\section{Diglosia}

Istilah diglosia pertama kali dikemukakan oleh seorang guru besar bahasa Inggris di Texas, sekitar tahun 1930-an. Kemudian pada tahun 1958 seorang sarjana Stanford C.A Fergusson mengutarakan ke dalam sebuah simposium. Ferguson dalam artikelnya yang berjudul "Diglossia" mendefinisikan diglosia sebagai berikut:

"Diglosia adalah suatu situasi bahasa yang relatif stabil, di mana selain dari dialek-dialek utama satu bahasa (yang mungkin mencakup satu bahasa baku atau bahasabahasa baku regional), ada ragam bahasa yang sangat berbeda, sangat terkodifikasikan, (sering secara gramatik lebih komplek), dan lebih tinggi, sebagai wahana dalam keseluruhan kesusastraan tertulis yang sangat luas dan dihormati, baik pada kurun waktu terdahulu maupun pada masyarakat ujaran lain, yang banyak dipelajari lewat pendidikan formal dan banyak dipergunakan dalam tujuantujuan oleh masyarakat apapun dalam pembicaraan biasa" 149 .

Pengkaijan oleh para linguis, akhir-akhir ini mengarah pada pengakuan bahwa dalam sebuah komunitas yang tampaknya diglosik terdapat tiga perangkat hubungan antara bilingualisme dan diglosia, yaitu: Bilingualisme tanpa Diglosia, Diglosia tanpa Bilingualisme, dan gabungan Bilingualisme dan Diglosia. Berikut ini akan dijelaskan tentang tiga perangkat tersebut: a. Bilingualisme tanpa Diglosia.

Contoh dari poin ini yaitu masyarakat Belgia yang tinggal di antara Belanda dan Perancis. Masyarakat ini

149Abdurrahman. Op. Cit,hlm 13-14. 
sama sekali tidak diglosik meskipun dalam kehidupannya mereka menggunakan lebih dari satu komunitas ujar, ini terjadi karena tidak ada kesepakatan diantara mereka apa yang menjadi bahasa nasionalnya. Dalam masyarakat belgia, bahasa Belanda dan Perancis memiliki status yang sama, yaitu menjadi bahasa resmi nasional (coequal National Official Status).

b. Diglosia tanpa Bilingualisme

Contoh dari kondisi ini adalah sebuah masyarakat yang biasanya memiliki strata sosial yang sulit dihilangkan. Dimana kelompok elite lebih memilih untuk mengisolir diri dari populasi yang lain yang diajak berkomunikasi. Kelompok elite tersebut lebih suka menggunakan bahasa asing yang berstatus tinggi yang digunakan dalam kelompok terbatas. Misalnya kaum elite Eropa sebelum tahun 1914-1918 yang lebih menyukai menggunakan bahasa Perancis atau jerman daripada bahasa setempat. Hal ini terjadi juga di negaranegara dunia ketiga, dimana kelompok elite lebih memilih bahasa yang diwarisi oleh kolonial sebelum merdeka daripada bahasa mereka sendiri.

c. Diglosia dan Bilingualisme

Contoh dari poin ini adalah masyarakat Indonesia sendiri, dimana kita memiliki bahasa resmi yang disepakati sebagai bahasa Nasional disamping kita juga memiliki bahasa-bahasa lain sebagai bahasa non-status atau tidak resmi. Contoh lain adalah negara Arab dimana mereka memiliki bahasa arab pasaran ('ammiyah) dan bahasa arab resmi (fusha). Di negara juga terdapat masyarakat ini, yaitu masyarakat 
Nurhapsari Pradnya Paramitha : Implementasi Pendekatan Sosiolinguistik

Paraguay, mereka menggunakan bahasa Guarani sebagai bahasa tidak resmi dan bahasa Spanyol sebagai bahasa resmi150.

\section{E. Pembagian Sosiolinguistik}

Para linguis membagi Sosiolinguistik dalam dua kelompok besar berikut, yaitu:

1. Sosiolinguistik Mikro

Kelompok ini menganalisis individu dalam interaksi intra kelompok yang kecil dan informal. Seperti, karakteristik seseorang yang membedakannya dengan individu yang lain, tingkah ujar, status keakraban, pertalian keluarga, sikap, bentuk-bentuk isyarat, kontak mata, jarak, dan lain-lain.

2. Sosiolinguistik Makro

Kelompok ini memberikan fokus kajian dalam interaksi pada tataran antar kelompok yang besar. Sehingga, bisa dipakai untuk mengkaji kontak antar bangsa dan Negara. Berusaha melihat perbedaanperbedaan bahasa di dalam masyarakat menurut umur, jenis kelamin, pekerjaan dan keanggotaan etnis dari pemakai bahasa yang dikaji. Mereka selalu mengkaji komunikasi antar kelompok di dalam konteks satu kelompok masyarakat. Misalnya, tentang penggunaan bahasa ibu dan bahasa lokal oleh kelompok linguistik minoritas, bekerja sama dengan para Sosiolog dan ahli pendidikan. Atau permasalahan-permasalahan berskala besar. Seperti, masalah memutuskan pemakaian bahasa

150 Abd. Syukur Ibrahim,Op. cit, hal. 205-209 
resmi yang dipakai untuk satu federasi Negara yang baru, perlindungan hak-hak kelompok linguistik minoritas 151 .

\section{F. Masalah-masalah Sosiolinguistik}

Masalah dalam Sosiolinguistik maksudnya adalah halhal yang merupakan topik-topik yang dibahas atau dikaji dalam sosiolinguistik. Masalah-masalah ini digagas dalam konferensi Sosiolinguitik yang pertama di Universitas of California, dari konferensi ini kemudian dirumuskan tujuh masalah yang dibicarakan dalam Sosiolinguistik, yaitu sebagai berikut: Identitas sosial penutur, Identitas sosial pendengar yang terlibat, Lingkungan sosial tempat perristiwa tutur, Analisis sinkronik dan diakronik dari dialek-dialek social, Penilaian sosial yang berbeda oleh penutur terhadap perrilaku bentuk-bentuk ujaran, Tingkatan variasi dan ragam linguistik, Penerapan praktis dari penelitian sosiolinguistik 152 .

Adapun masalah-masalah atau topik-topik dalam Sosiolinguistik menurut Nababan, sebagai berikut153:

1. Bahasa, Dialek, dan Idiolek

Perbedaan ketiga istilah ini dapat dilihat dari definisi masing-masing. Jika yang dibicarakan adalah bahasa seseorang atau ciri khas yang dimiliki seorang individu dalam menggunakan bahasa maka ia disebut idiolek. Idiolek seseorang akan berbeda dengan indivudu lain. Jika idiolek-idiolek lain dapat digolongkan dalam satu kumpulan kategori, maka ia disebut dialek. Jadi, dialek itu

151Abd. Syukur Ibrahim, Op. cit, hal.43, lihat juga Mark Aronoff And Janie Rees-Miller, Op. cit. hlm 430-432

152Aslinda dan Leni Syafyahya, op. cit, hal.7 153Ibid hlm.7

178 Jurnal Komunikasi dan Pendidikan Islam, Volume 6, Nomor 2, Desember 2017 
merupakan ciri khas sekelompok individu atau masyarakat dalam menggunakan bahasa.

\section{Verbal Repertoire}

Diartikan sebagai kemampuan berkomunikasi yang dimiliki oleh penutur. Artinya, penutur mampu berkomunikasi dalam berbagai ragam bahasa kepada pihak lain dalam berbagai ujaran.

3. Masyarakat Bahasa

Ia adalah sekelompok orang yang satu sama lain bisa saling mengerti ketika mereka melakukan interaksi dan transmisi pengetahuan dengan berbicara. Baik dalam sekompok orang yang menggunakan bahasa yang sama atau bahasa yang berbeda dengan syarat diantara mereka terjadi saling pengertian.

4. Kedwibahasaan atau Kegandaan

Maksudnya adalah kebiasaan atau kemampuan yang dimiliki oleh penutur dalam menggunakan bahasa. Banyak aspek yang berhubungan dengan kajian kedwibahasaan antara lain, aspek sosial, individu, pedagogis dan psikologis. Kata kedwibahasaan mengandung dua konsep, yaitu; kemampuan menggunakan dua bahasa (bilingualitas) dan kebiasaan menggunakan dua bahasa (bilingualism). Dalam konsep yang pertama dibicarakan tingkat penguasaan bahasa dan jenis keterampilan yang dikuasai. Sedangkan pada konsep yang kedua dibicarakan pola-pola penggunaan dua bahasa, seringnya dipergunakan setiap bahasa, lingkungan bahasa, dan bagaimana bahasa-bahasa itu dipergunakan. Dalam kedwibahasaan juga 
dibicarakan masalah alih kode (code switching), campur kode (code mixing), interferensi, dan integrasi 154.

5. Fungsi Kemasyarakatan dan Kedudukan Kemasyarakatan Bahasa

Kita tahu bahwa bahasa memiliki fungsi-fungsi tertentu dalam pergaulan diantara sesama anggota sesuai dengan kelompok atau suku bangsa. Ia memiliki peran yang sangat penting, dimana ia menajdi alat komunkasi antara masyarakat yang satu dengan yang lainnya. Dalam sebuah komunitas masyarakat yang majemuk, bahasa pemersatu (lingua franca) sangatlah penting. Contohnya adalah bahasa Indonesia, ia menjadi bahasa nasional, bahasa Negara, bahasa resmi, dan bahasa persatuan antar suku bangsa.

6. Penggunaan Bahasa atau Etnografi Bahasa

Dalam penggunaan bahasa, penutur harus memperhatikan unsur-unsur yang terrdapat dalam tindak berbahasa dan kaitannya atau pengaruhnya terhadap bentuk dan pemilihan ragam bahasa. Dalam penggunaan bahasa ada delapan unsur yang harus dipehatikan. Agar mempermudah pemahaman dalam konsep ini kemudian ia disingkat menjadi SPEAKING (Setting: tempat peristiwa tutur terjadi, Participant: siapa saja pengguna bahasa, Ends: maksud dan tujuan yang ingin dicapai dalam aktivitas berbicara, Act sequences: bentuk dan isi suatu tuturan, Key: nada suara, sikap atau cara berbicara, Instrumentalities: channel dan bentuk bahasa yang digunakan untuk menyampaikan pesan, Norm: kaidahkaidah tingkah laku dalam interaksi dan interpretasi

154Abd. Syukur Ibrahim, Op. cit, hlm. 181

180 Jurnal Komunikasi dan Pendidikan Islam, Volume 6, Nomor 2, Desember 2017 
komunikasi, dan Gentre: kategori yang dapat ditentukan lewat bentuk bahasa yang digunakan).

7. Sikap Bahasa

Dikaitkan dengan motivasi belajar suatu bahasa. Sikap bahasa adalah kesopanan berelasi terhadap suatu keadaan. Sikap mental dan sikap perilaku dalam berbahasa. Tentu kita telah memahami bahwa cara berbahasa seseorang sangatlah mempengaruhi penilaian seseorang terhadap penutur. Bagi orang Jawa misalnya, cara berbahasa seseorang memiliki arti yang sangat penting, karena kita bisa menilai perilaku dan akhlak penutur. Oleh karena itu, kita menemukan sebuah ungkapan tentang sikap bahasa dalam bahasa Jawa; "Ajining diri ono ing lathi"(cara kamu berbahasa, menunjukan siapa kamu sebenarnya).

8. Perencanaan Bahasa

Berhubungan dengan proses pengembangan bahasa, pembinaan bahasa, dan politik bahasa yang disusun berdasarkan ketentuan-ketentuan yang telah digariskan oleh kebijaksanaan bahasa. Dan harus meliputi dua aspek pokok yang berhubungan dengan kedudukan bahasa atau status bahasa dan yang berhubungan dengan materi bahasa atau korpus atau kode 155 .

9. Interaksi Sosiolinguistik

Membicarakan tentang kemampuan komunikatif penutur. Dibicarakan juga makna yang sebenarnya dari unsur-unsur kebahasaan karena satu kata dapat memiliki makna ganda. Meski konsep tentang makna sampai sekarang masih terus menjadi pembahasan yang tiada

155Abd. Syukur Ibrahim, Op. cit, hlm. 252 
akhir, tetapi dalam konteks interaksi sosiolinguistik makna bahasa lebih bisa untuk dimengerti.

10. Bahasa dan Budaya

Para Antropolog memberikan perhatian yang yang besar terhadap bahasa dan kebudayaan maupun bahasa dalam kebudyaan. Mereka secara konsisten telah mengjajaki hubungan antara bahasa dan kebudayaan, bukan saja karena bahasa tidak bisa dipisahkan dari budaya akan tetapi juga karena ada pengakuan bahwa aktivitas budaya sesederhana apapun selalu menyangkut dan terletak pada gagasan-gagasan; dan gagasan hanya beroperasi dan berpindah melalui ujaran atau bahasa156.

\section{G. Urgensi Sosiolinguistik dalam Pembelajaran Bahasa}

Banyak faktor yang mendukung kesuksesan pembelajaran bahasa, misalnya: tujuan pembelajaran, bahan pelajaran, sumber belajar157, dana dan sarana, siswa, dan guru. Kesuksesan pembelajaran bahasa tidak mungkin mencapai titik sukses jika hanya menonjolkan salah satu faktor dan mengabaikan faktor yang lain. Semua faktor di atas harus berjalan beriringan dan dinamis 158 .

156Abd. Syukur Ibrahim, Op. cit, hlm.. 99-102

${ }_{157}$ Pembahasan yang cukup lengkap mengenai bahan pelajaran dan sumber belajar atau materi Bahasa Arab dapat di baca dalam H.M Abdul Hamid, dkk, Pembelajaran Bahasa Arab: Pendekatan, Metode, Strategi, Materi, dan Media, (Malang: UIN-Malang Press, 2008), hal. 69-128, baca juga Dr. Suja'i, M. Ag, Inovasi Pembelajaran Bahasa Arab: Strategi dan Metode Pengembangan Kompetensi, (Semarang: Walisongo Press, 2008), hal. 13-37

${ }_{158}$ Selain faktor diatas, ada faktor lain yang tidak kalah pentingnya juga dalam menopang kesuksesan pembelajaran bahasa, yaitu kita juga diminta untuk memperhatikan faktor-faktor yang mempengaruhi pemilihan strategi belajar mengajar. Dalam uraian yang dijelaskan oleh Prof. Dr. Iskandarwassid, M. Pd., setidaknya ada enam faktor yang juga harus diperhatikan yaitu: karakteristik peserta didik, kompetensi dasar yang diharapkan, bahan ajar, waktu yang tersedia, sarana atau prasarana belajar, 182 Jurnal Komunikasi dan Pendidikan Islam, Volume 6, Nomor 2, Desember 2017 
Nurhapsari Pradnya Paramitha : Implementasi Pendekatan Sosiolinguistik

Untuk lebih memahami faktor-faktor itu, berikut ini kami sertakan bagan mengenai faktor-faktor pembelajaran tersebut, sebagaimana yang di jelaskan oleh Sudirman dalam Mamluatul Hasanah:

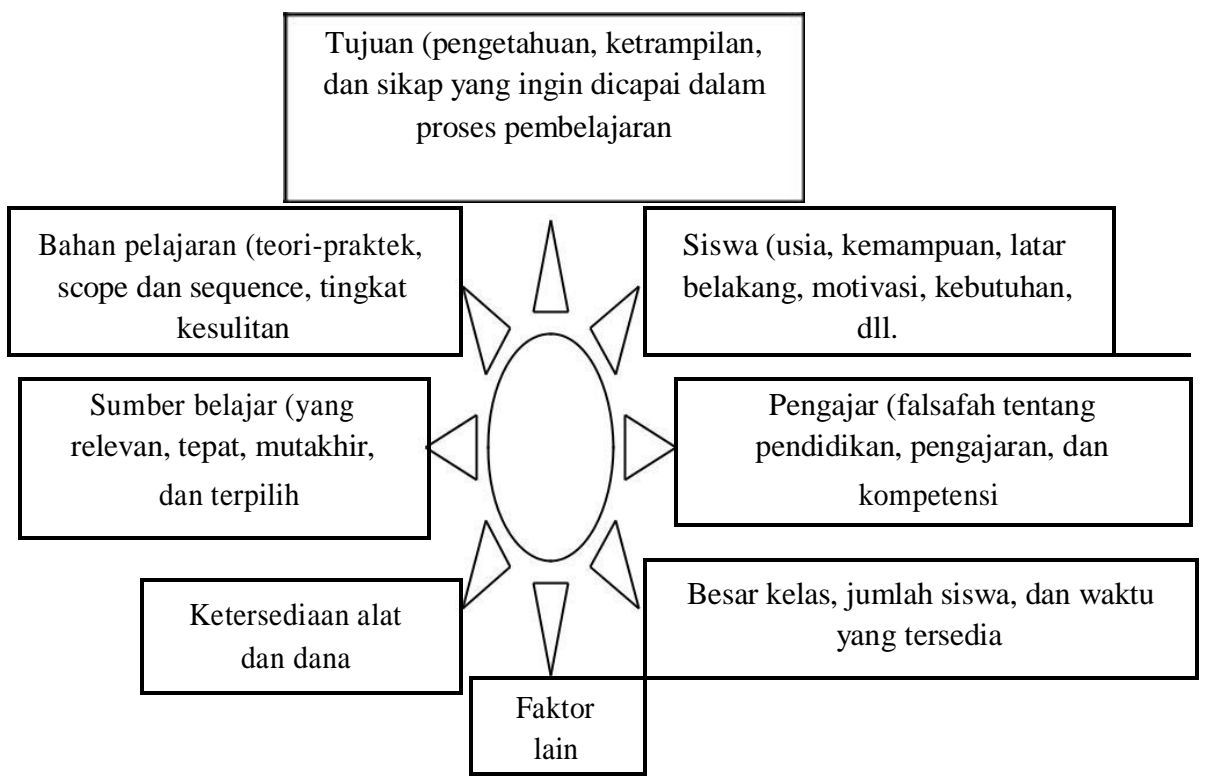

Selain itu, penting juga bagi kita untuk mengetahui faktor-faktor yang menunjang keberhasilan dalam pembelajaran Bahasa Arab. Dr suja'i membagi faktor ini ke dalam dua bagian, yaitu: faktor-faktor Internal dan eksternal.

1. Faktor-Faktor Internal

Faktor ini berasal dari diri setiap orang yang ingin mempelajari Bahasa Arab, dimana ia bisa membantu dan mendukung juga memberi semangat kepadanya agar lebih giat guna mencapai target yang diinginkan. Relasi antara

dan kemampuan atau kecakapan pengajar dalam memilih dan menggunakan strategi pembelajaran bahasa. Iskandarwassid dan Dadang Suhendar, Strategi Pembelajaran Bahasa, (Bandung: PT. Remaja Rosdakarya, 2008), hal. 168-174 
semangat dan tingkat ketekunan seseorang selalu berbanding lurus. Jika ia memiliki semangat yang tinggi dalam dirinya untuk belajar maka ia akan semakin rajin dan tekun dalam mempelajari Bahasa Arab, dan begitu juga sebaliknya.

Adapun faktor-faktor internal itu antara lain: keadaan fisik atau jasmani seseorang, keadaan jiwa atau psikologisnya, tingkat kemampuan atau intelegensianya, bakat dan minat, dan kematangan dalam belajar. Namun dari semua faktor itu, faktor bakat dan minat merupakan hal yang paling penting. Karena ia menjadi modal awal dalam mendukung faktor-faktor internal lainnya. Orang yang tidak memiliki minat dalam mempelajari Bahasa Arab dirasa mustahil dapat mendapatkan manfaat yang banyak dari proses pembelajarannya.

2. Faktor-Faktor Eksternal

Selain faktor-faktor internal tadi, tidak kalah pentingnya faktor eksternal dalam pembelajaran Bahasa Arab. Kondisi diluar peserta didik juga dapat memperkuat atau memperlemah faktor-faktor internalnya. Diantara faktor-faktor eksternal itu adalah: keluarga, tempat belajar, dan masyarakat. Keluarga memiliki pengaruh terhadap aspek dan keberhasilan belajar peserta didik. Keluarga yang harmonis, yang memberikan dukungan penuh, tentu akan berbeda pengaruhnya terhadap peserta didik dibanding dengan keluarga yang hancur (broken home) dan tidak mendukung pendidikannya.Kondisi tempat belajar juga memberikan sumbangsih yang besar terhadap pembelajaran. Kelengkapan fasilitas, keadaan yang kondusif, materi dan metode yang diberikan guru, 
hubungan antara guru dan peserta didik, tentu memiliki pengaruh yang sangat besar dalam keberhasilan pendidikan.

Sumbangsih yang mungkin diberikan masyarkat dalam pembelajaran Bahasa Arab adalah sebagai tempat praktek teori yang telah didapatkan. Masyarakat bahasa (Biah Lughawiyah) memiliki andil yang besar bagi seorang peserta didik sebagai tempat mempraktekan bahasa. Karena masyarakat Bahasa Arab sangat jauh dan membutuhkan biaya yang tidak sedikit, biasanya dalam pembelajaran Bahasa Arab di Indonesia membuat masyarakat bahasa tersendiri159.Selain itu, Pembelajaran bahasa membutuhkan empat konsep dasar, setidaknya ada empat konsep yang penting dan kita akan melihat di mana letak urgensi Sosiolinguistik dalam pembelajaran bahasa, yaitu:

a. Pembelajaran bahasa memerlukan konsep hakekat bahasa. Setidaknya seorang pembelajaran bahasa akan mengajukan pertanyaan tentang apa sebenarnya bahasa dalam pembelajaran bahasa, pertanyaan ini akan dijawab oleh Linguistik, Psikolinguistik dan Sosiolinguistik.

b. Pembelajar bahasa menuntut pandangan tentang pembelajar bahasa dan bahan ajar bahasa. Hal yang mendasar dari pandangan ini diajukan dalam pertanyaan siapa yang sedang belajar bahasa dan bahan ajar apa yang semestinya diberikan. Jawaban dari pertanyaan ini akan dijawab oleh Psikologi Pendidikan, Psikolinguistik, dan Sosiolinguistik. 
c. Guru memiliki posisi penting dalam pembelajaran bahasa. pertanyaan dari poin yang ketiga ini seputar bagaimana sebenarnya teori pembelajaran dan tugas serta peran seorang guru dalam pembelajaran, jawaban ini akan dijawab oleh Studi Pendidikan.

d. Pembelajaran berlangsung dalam konteks tertentu. Bahasa, belajar bahasa, dan mengajar bahasa harus dilihat dalam konteks apa, bagaimana setting pendidikannya, dan apa latar belakang dilakukannya pembelajaran bahasa. dalam konteks bahasa ia berperan dalam memahami kondisi masyarakat dimana bahasa itu diajarkan dan bagaimana sosiolinguistiknya 160.

\section{H. Kontribusi Sosiolinguistik dalam Pembelajaran Bahasa}

Pembelajaran bahasa tidak mampu mandiri tanpa melibatkan ilmu yang lain yang relevan dengannya, seperti: Psikologi, Pedagogik, Sosiologi, Antropologi, Manajemen, Sosiolinguitik, Psikolinguistik, dan Linguistik. Sosiolinguistik merupakan bagian dari linguistik terapan dimana ia berusaha menjembatani antara teori dan praktek yang disebabkan oleh perbedaan sikap, metode, dan tujuan kedua kelompok tersebut. Dari segi tujuan Linguistik berusaha menemukan kriteria atau teori universal yang akan menerangkan fenomena bahasa sedangkan guru bahasa bertujuan membantu murid menguasai bahasa. Lalu dari segi Metode Linguistik menggunakan metode formal dan abstrak, sedangkan guru bahasa menggunakan Metode Fungsional yang praktis. Dari sisi sikap lingustik melihat bahasa sebagai

160Mamluatul Hasanah, Sosiolinguistik dan Pembelajaran Bahasa: Sebuah Kajian Linguistik Edukasional, (Malang: Fakultas Humaniora dan Budaya UIN Malang, 2005) hlm. 74-75

186 Jurnal Komunikasi dan Pendidikan Islam, Volume 6, Nomor 2, Desember 2017 
suatu sistem, sedangkan guru bahasa melihat bahasa sebagai suatu ketrampilan 161.

Selain itu, Sosiolinguistik juga merupakan salah satu ilmu bahasa terapan yang mempelajari tentang problematika dialek suatu daerah dan juga topik Bilingual dan Multilingual. Kontribusi Sosiolinguistik dalam pembelajaran bahasa dalam aplikasi Linguistik dibagi menjadi tiga tahap, yaitu:

1. Tahap Deskripsi Linguistik. Tahap ini memberi jawaban atas pertanyaan umum tentang hakekat bahasa yang diajarkan. Tahap ini tidak menjawab tentang apa yang akan diajarkan atau susunan sebuah pembelajaran

2. Tahap aplikasi kedua berhubungan dengan soal silabus. Kita tidak mungkin mengajarkan semua materi dalam bahsa, karenanya kita harus membuat desain pembelajaran berupa pemilihan bahan agar mendapatkan hasil yang maksimal

3. Tahap aplikasi ketiga yaitu tahap kegiatan pembelajaran bahasa. karena pada tahap kedua ini belum bisa membuat silabus yang lengkap dan utuh, maka kaidah-kaidah penyusunan silabus perlu memperhatikan faktor Linguistik, Psikolinguistik, dan Sosiolinguistik162.

\section{Kesimpulan}

Dapat disimpulkan bahwa Sosiolinguistik merupakan cabang Linguistik yang bertujuan menemukan prinsip-prinsip yang mendasar didalam memahamai cara bekerjanya bahasa dengan jalan yang lebih komprehensif dan dengan melibatkan

161Mamluatul Hasanah, op. cit, hlm. 76-77

162Jis Daniel Parera, Linguistik Edukasional: Pendekatan Konsep dan

Teori Pengajaran Bahasa, (Jakarta: Erlangga, 1987) hlm. 11-13 
perhitungan pengaruh berbagai konteks sosial yang menjadi jalinannya.

Adapun manfaat sosiolinguitik itu adalah:

1. Sosiolinguistik dapat memberikan gambaran tentang keadaan sosial suatu masyarakat berkaitan dengan bahasanya.

2. Sosiolinguistik dapat digunakan untuk mendeskripsikan adanya variasi-variasi yang ada dalam masyarakat tertentu,Sosiolinguistik dapat membantu untuk menentukan atau memilih variasi bahasa mana yang akan kita gunakan yang sesuai dengan situasi dan fungsinya.

3. Sosiolinguistik dapat digunakan untuk mendefinisikan perubahan bahasa secara sempurna sesuai dengan faktorfaktor kebahasaan.

4. Sosiolinguistik dapat membantu untuk menunjukkan bahwa aspek linguistik merupakan fenomena penting dalam perilaku masyarakat, dan sebagai sebab kemajuan individu dalam masyarakatnya

Penerapan Sosiolinguistik dalam pembelajaran bahasatidak secara eksplisit dapat kita temukan. Kita pahami bersama bahwa Sosiolinguistik merupakan salah satu ilmu bahasa terapan yang mempelajari diantaranya tentang problematika dialek suatu daerah dan juga topik Bilingual dan Multilingual. Kontribusi Sosiolinguistik dalam pembelajaran bahasa dalam aplikasi linguistik dibagi menjadi tiga tahap, yaitu:

1. Tahap deskripsi Linguistik. Tahap ini memberi jawaban atas pertanyaan umum tentang hakekat bahasa yang diajarkan. Tahap ini tidak menjawab tentang apa yang akan diajarkan atau susunan sebuah pembelajaran 
2. Tahap aplikasi kedua berhubungan dengan soal silabus. Kita tidak mungkin mengajarkan semua materi dalam bahsa, karenanya kita harus membuat desain pembelajaran berupa pemilihan bahan agar mendapatkan hasil yang maksimal

3. Tahap aplikasi ketiga yaitu tahap kegiatan pembelajaran bahasa. karena pada tahap kedua ini belum bisa membuat silabus yang lengkap dan utuh, maka kaidah-kaidah penyusunan silabus perlu memperhatikan faktor Linguistik, Psikolinguistik, dan Sosiolinguistik. 
Nurhapsari Pradnya Paramitha : Implementasi Pendekatan Sosiolinguistik

\section{DAFTAR PUSTAKA}

Abdurrahman. 2007.Makalah Sosiolinguistik: Campur Kode, Alih Kode dan Karakteristik Bahasa Sastra dalam sebuah Novel Bekisar Merah. Malang: UIN-Malang Press

Aronoff, Mark And Janie Rees-Miller. 2002. The Handbook of Linguistics. UK: Blackwell Publishing

Aslinda dan Leni Syafyahya. 2007. Pengantar Sosiolinguistik. Bandung: PT. Refika Aditama

Basyar, Kamal. 1997. Ilm al Lughoh al Ijtima’i. Kairo: Dar Gharib

Daud, Muhammad. 2001. Al 'Arabiyah wa al Ilm al Haditsah. Kairo: Dar gharib

Farkhan, Muhammad. 2008. Applied Linguistics. ELL Journal, Vol. 1, No. 2, September 2008

_ 2008. Sociolinguistics: A Basis for Language Use Analysis.ELL Journal, Vol. 1, No. 1, March 2008

Hasanah, Mamluatul. 2005. Sosiolinguistik dan Pembelajaran Bahasa: Sebuah Kajian Linguistik Edukasional. Makalah dalam Jurnal Lingua: Jurnal Ilmu Bahasa dan Sastra Volume III/Nomor 1/September 2005. Malang: Fakultas Humaniora dan Budaya UIN Malang.

Hamid, H.M Abdul, dkk. 2008. Pembelajaran Bahasa Arab: Pendekatan, Metodologi, Strategi, Materi, dan Media. Malang: UIN-Malang Press

Hudson, Richard A.1980. Sociolinguistics. Cambridge: University Press

Ibrahim, Abd Syukur. 1995. Sosiolinguistik Sajian, Pendekatan dan Problem. Surabaya: Usaha Nasional

Iskandarwassid dan Dadang Suhendar. 2008. Strategi Pembelajaran Bahasa. Bandung: PT. Remaja Rosdakarya

Mahmudah, Umi dan Abdul Wahab Rosyidi. 2008. Active Learning dalam Pembelajaran Bahasa Arab. Malang: UIN-Malang Press 
Muhammad Syahin, Taufiq. 1980.Im Al-Lughoh Al-Amm. Mesir: Maktabah Wahbah

Nababan, P.W.J.1993. Sosiolinguistik: Suatu Pengantar. Jakarta: Gramedia Pustaka Utama

Poedjosoedarmo, Soepomo. 1986. "Kode dan Alih Kode", dalam jurnal Widyaparwa 15. Yogyakarta: Balai Penelitian Bahasa

Suja'i. 2008. Inovasi Pembelajaran Bahasa Arab: Strategi dan Metode Pengembangan Kompetensi. Semarang: Walisongo Press

Suwito. 1996. Sosiolinguistik. Surakarta: Sebelas Maret University Press

Zakaria, Misyal. 1987. al Alsaniyyah al Taulidiyah wa al Tahwiliyah wa Qawa'idi al Lughoh al 'Arabiyyah. Beirut: al Hamra 